\title{
The anvil: a crushing conversation
}

\author{
Lindy Grief Davidson, Adam W. Davidson \\ University of South Florida, Tampa, Florida, USA
}

\begin{abstract}
In this collaboratively written piece, the authors narrate the most crushing day of their life. Their reflections reveal their different yet resonating perceptions of finding out bad news about their first child during pregnancy. The authors seek to investigate the parental experience of receiving a devastating diagnosis for a child by placing two accounts of the same event side-by-side. While illness stories abound, they often represent only one viewpoint. The authors seek to provide a study of life in the midst of a crisis, which is rarely what it seems from the outside looking in. Additionally, by using the accessible format of personal narrative, they provide a piece of research for a more diverse audience.
\end{abstract}

There is a problem with the baby. These words, dreaded by every expectant parent, came spilling forth from the doctor's mouth like a summons we could not escape. That was a defining moment, perhaps the defining moment that altered the course of our lives. It was not a summons to appear for a judgment, but a summons to live differently, to walk an unknown path. We immediately realized the many potential losses we faced in that different life, but we did not know and could not have known the depth of life, joy and goodness we would come to experience when we began walking that dark journey together.

A clear line marks before and after this moment in my life. On one side is the life I had before March 12, 2002, a life represented by a studio portrait of my husband and me poised in perfect position, smiling directly into the camera lens. On the other side is the life I have now, a life represented by our favorite family photo in which my husband and I are engaged in a tickle fight with our three boys. Everyone is laughing and no one is paying attention

Correspondence: Lindy Grief Davidson, University of South Florida Honors College, Tampa, Florida, USA

E-mail: lindyd@mail.usf.edu

Key words: Pregnancy; Devastating diagnosis; Illness; Child.

Conflict of interest: the authors declare no potential conflict of interest.

Received for publication: 14 June 2016.

Revision received: 27 September 2016.

Accepted for publication: 28 September 2016.

This work is licensed under a Creative Commons Attribution NonCommercial 4.0 License (CC BY-NC 4.0).

(C) Copyright L. Grief Davidson and A.W. Davidson, 2017

Licensee PAGEPress, Italy

Qualitative Research in Medicine \& Healthcare 2017; 1:6-13

doi:10.4081/qrmh.2017.6086 to the camera. Around my house, we call the previous time, before Will. And frankly, anything that happened before Will is a blur. The cast of characters present in the dividing moment includes Adam (my husband), a doctor, and me. To add another perspective to my account, I include Adam's voice. His rendition of the event adds color and depth where mine falls flat. He poetically depicts some of the events I remember as sterile and pragmatic. We investigate the parental experience of receiving a devastating diagnosis for our first child by bringing our private moment into the public eye. ${ }^{1}$ It is our hope that readers will, as Frank says, ${ }^{2}$ think with our story by considering our cognitive and emotional responses of fear and faith as we move through and past the most traumatic day of our lives. Additionally, our story adds to the growing yet still underrepresented patient and family accounts. Through this account, we invite healthcare professionals into our home, thoughts, feelings and daily experiences to give a fuller view of what they experience with patients and families in the clinical setting.

Ellis and colleagues explain autoethnography as an approach to research and writing that seeks to describe and systematically analyze personal experience in order to understand cultural experience (273). ${ }^{3}$ Using thick description, writers produce texts that are accessible and challenge the norms of scientific research by acknowledging the importance of the process of research as well as the product. Autoethnography is concerned with both personal and social change and therefore seeks to be accessible to a wider and more diverse audience often disregarded by traditional research.

Narratives such as this one engage two authors' experiences of an event. Specifically, co-constructed narratives aim to show how people collaboratively cope with the ambiguities, uncertainties, and contradictions of being friends, family, and/or intimate partners (279). ${ }^{3}$ When two authors collaborate on autoethnography, the result is a social science research method that preserves the unique strengths of self-reflexivity associated with autobiography, 
cultural interpretation associated with ethnography, and multi-subjectivity associated with collaboration (17). ${ }^{4}$

Using the ideas of autoethnography as modeled by scholars such as Ellis and Bochner and Rennels and Paxton, ${ }^{1,5}$ Adam and I approach our story with the understanding that the event we describe played a major role in the construction of our marriage. Facing the crisis of a child in peril forced us into making decisions about the ways in which we would relate to one another and to our child, fully aware that such a crisis can be devastating to a marriage. Some readers will find similarities in their own experiences, but may not have been able to talk about them (84). ${ }^{6}$ As one story tends to evoke more stories, ${ }^{7}$ perhaps telling of our experience will inspire other couples to talk about their own experiences, feelings, fears and hopes because, while illness stories abound, they often represent only one viewpoint. Finally, we hope to provide a study of life in the midst of a crisis, which is rarely what it seems from the outside looking in. Specifically, we offer our story to show that parents face difficult decisions for their children from a position that may not be recognized by healthcare providers. A family's story is greater than a medical diagnosis.

This project began as an individual endeavor to tell my story about receiving bad news from a doctor. After a few drafts, I invited Adam into the process and asked him to write his own version without seeing what I produced. After reading one another's versions, we were amazed at how well they complemented one another. We focused on different moments within the event, so by placing them together, we created something beyond our independent tellings. Although we consistently re-lived this story orally, we had never written it together. Upon reading one another's written accounts, we could see how the details of the story differed, and how we as characters differed in the tellings. Reading my name as a supporting character in Adam's story allowed me to understand more about his unique perspective. ${ }^{8}$ Yet the plot and one critical scene in particular were remarkably the same. I integrated most of Adam's writing into my original story. During the editing process, we discussed the paper and events described, our emotional responses, surprises at one another's reactions, and new perspectives gained by years of hindsight. Drafts were passed back and forth with me acting as principal editor. The process was time-consuming and emotional as I carefully interrogated my memory of and emotions about a life-changing moment. Our storying of the event further solidified our emotional and spiritual bond rooted in Christian faith, hope and love. We chronicle the events of the day our lives took an unforeseen turn and then reflect on how we made sense of that event..

Adam's:

The memory of that day falls like shadow when the sun is still on the horizon and highlights the tops of the trees, leaving the ridges in full relief against the blue-black of the emerging night. Most of what I can see in my mind's eye is in the understory, obscured and darker than you expect with the leaves still bright above. I walk through the grey-ness, a little by feel and a little in conjecture.

Of that day, I remember most vividly my own looming worry and guilt. I tend to think the predictable worst of situations. In some ways, it is simply the result of being a planner as I work out details in my head to anticipate obstacles and strategize to avoid them. Pregnancy, however, brought on more than the normal worries and fears. I also became obsessed with the question, What if my child is sick or dies? I could not shake the tendency to wonder whether we had won that lottery.

I was already battling my thoughts as we pulled into the parking lot of the squatty cube-ish building in the middle of a much larger medical park. After a night of brooding and stewing on the ominous news about our child, that there appeared to be too much fluid in and around the kidneys, I couldn't help but feel a twinge of guilt that I had somehow brought all of this on as a sick sort of self-fulfilling prophecy. Had I worried my child into a tragic situation?

I compounded the nagging anxiety with my frustration over feeling unwarranted guilt. It was a vicious cycle of bad thinking, worry compounded by guilt over being worried about a potential diagnosis and frustration with my guilt and worry. My thoughts were out of control.

On a sunny March day, Adam and I pull up to a medical office building downtown. Karen says she saw the same doctor, and he told Karen one of her baby's kidneys looked a little small, but they would just watch it. She says she's not really worried.

Adam interrupts my chatter to bring me back to the task at hand, What floor is it?

The nurse said 240, so I guess the second floor.

Adam's:

It was a confined space full of impersonal, outdated reminders of where we were: a strange building, a stranger's office, a specialty in medicine to which I had never given a single thought before that moment: perinatology. I wasn't even sure how to spell this man's name. An elevator ride to a long forgotten floor. A right turn down a narrow hallway and into a medical office-suite. A check-in desk on the right.

We enter a door marked Fetal Diagnostic Center and go through the usual doctor's office routine of signing a clipboard and handing over forms of identification, insurance, and payment. We are directed to a seating area near the desk. 
Sitting on an upholstered chair, I take in my surroundings. The waiting area, with rose-colored walls trimmed by pristine white architectural columns is nice, too nice. A glass table occupies the middle of the floor, surrounded by couches and chairs like the ones found in an empty formal living room of a home that is otherwise bustling. For all the pretense of a living room, the pungent smell of institutional cleaner betrays the place as unmistakably medical. The worn, dirty, white binder atop a glass lamp table seems out of place in this sterile room, almost as out of place as I hope I am. Without getting caught staring at her belly, I try to determine how pregnant the woman sitting across from me is. I wonder what is wrong with her as I try to dismiss what might be wrong with me. Your fluid is a little low, said the nurse over the phone yesterday morning. I made you an appointment with a perinatologist at nine o'clock tomorrow morning. So here I sit with Adam. We wait.

\section{Adam's:}

I have no memory of a waiting area or of waiting. Of course, they knew we were coming, but in my memory we were not just a name on an appointment registry. We were already familiar to them, the path cleared and made ready. I was in a strange movie dream-sequence where the doorman invites the sleepwalker into the ballroom like he's seen him a thousand times and yet, the walker has no prior memory of this place.

We WILL get some video this time, I say to Adam, faking confidence. My sweaty palms press against a blank VHS tape. He smiles, but I can tell he's faking too. I plan to show the sonogram video to friends and family now, and eventually, show it to the star of the show when our child is old enough to understand. Four days ago, a stoic and silent sonographer denied me the opportunity to record my first look at my first baby. Instead of a fun family video, I got an hour lying on a hard table, eventually crying because I needed to pee so badly. The sonographer made Adam wait in the lobby, so I was left alone with her and the gloomy cloud she projected. Dismissing my expectations for the sonogram, she made little effort to discern the baby's gender. The whole event was supposed to be exciting and revelatory; instead it turned out to be disappointing. As a high school senior, I received the superlative most likely to succeed. I took this as a life-long personal challenge rather than an award. Defeat, failure and disappointment threaten success, and I expect to have success, perhaps even to embody success. I'm not accustomed to disappointment.

I look at the binder on the table. A picture album? Maybe. Survival stories probably. Any move in the direction of the binder feels like submission. The binder is a door into a world I do not care to enter, a world of medical crises where people pull through and after grand ordeals and great pains write letters of gratitude to the doctor who aided their survival. I don't like the idea of living survival. I want to pick out the crib, register for gifts, find out if it is a boy or girl and avoid any grand ordeals. The binder is a portal to medical crisis, and I am determined it will not suck me into its vortex.

Lindy!!! My name bounces off the high-end tile floor, and Adam and I dutifully rise to our feet and follow the nurse. She takes my blood pressure, asks me about cycle dates and escorts us to an exam room. The paper crinkles as I sit down on the large pink vinyl chair next to the sonogram machine. The sonographer introduces herself with a smile that communicates warmth and friendship, I'm Valerie.

\section{Adam's:}

Valerie was there. We saw her so many times over the next few months that I will never forget her face and smile, but that day, I was blind to those gifts. Looking at her well-manicured fingernails and her make-up led me to assume she cared too much for her appearance. It was a surface evaluation that, as I reflect, only indicated my own shallow obsession with appearances. My flawed thinking encouraged me to dismiss her. Nevertheless, her brightness and concern for me as a helpless spectator in the medical drama that followed taught me otherwise. Valerie became my friend and companion over the next few months. She endured all the same sights and sighs with so much cheer and confidence. Reassuring, checking, encouraging, translating doctor-speak, distracting (with small talk about our favorite restaurants), Valerie occupied an essential part of our new world, not only for her technical skill as the doctor's primary assistant, but also as a mentor in cheerful endurance.

The sonographer of four days ago was Stalin compared to Valerie, who quickly obliges my request to record the sonogram on video. Finally, something is going right! The doctor comes in and introduces himself as Dr. Al-Masry, not O'Malley, as I had written down with the appointment information. I envisioned someone Irish with a playful brogue. Dr. Al-Masry, we learn, is Middle-Eastern. His presence is larger than his stature, and his dark eyes and kind touch win my trust immediately. After we capture approximately ten seconds of sonogram video, Dr. Al-Masry says, Hmmm. I need to put in my own tape.

While his tape is recording, he speaks calmly. We see the baby on the screen and smile at the discovery that our first child has his mother's profile, complete with turnedup nose and deep-set eyes. The elation of the image, our baby's image, our image, rises up to meet the anxiety that has already begun to inundate our souls.

After several minutes of sonogram, complete with printed pictures, someone escorts Adam and I to a small conference room filled with three chairs, a TV/VCR, and a box of tissues strategically placed in the center of the 
round table. For a few minutes, Adam and I sit alone in this room filled with dread and uncertainty. Then, Dr. AlMasry joins us. The air is thick with our silence. The binder from the waiting room has nothing on that menacing box of tissues.

\section{Adam's:}

At some point we are transported down the hall to the room with the round table, the box of tissues in the middle and the small TV/VCR combo on the filing cabinet. It was a horribly small space, confined and quiet - clearly an afterthought in the world of doctor's office architecture and spatial planning. It was probably labeled office on the blue prints or maybe supply closet. That day, it was our black hole, where most of what we thought was our life, present and future, succumbed to the gravitational pull of our new medical crisis and disappeared in the darkness.

Dr. Al-Masry comes in, says a few words, plays the VHS tape of the sonogram, points out problems, and says more words. An anvil falls on our heads. The anvil comes down with the crushing news of a baby in peril, a baby who has suffered kidney damage, bladder damage and potentially fatal lung damage. In that moment, in that tiny conference room, I am crushed. While my baby's life is not over, the life I thought I would have sits beneath a tenton anvil. That life is over.

Adam's:

It was difficult for me to wrap my mind around what was happening here. A barrage of new medical terms, uncertain diagnoses, and unknown consequences descended upon us, and we were completely unprepared, like soldiers sitting around the campfire making coffee, weapons leaned against a nearby log suddenly under attack by an unseen enemy. If we could have scattered we just might have. The loudest thing in my head was not the danger facing my child, who was still a bit theoretical at this point, barely beyond imagination in Lindy's little baby bump and the awkward and grainy sonogram images we had just seen. My mind was racing on thoughts of my own life slipping away; thoughts of a $\mathrm{PhD}$ and recognition and accomplishment and stability and comfort and control, all spiraling into the dark like the sparks from that campfire now doused and strewn about in the melee.

I was beginning to mourn the loss of my own life. Certainly, my physical life was intact, but my personal vision for my future, the well-ordered steps in the line of ascent towards my dreams proved not merely poorly conceived, but totally wiped off the map. This news was stripping away part of my personal identity. Although my dreams were speculative and illusory, at the time it felt as if part of me was dying.
Dr. Al-Masry explains that our baby is not peeing. His bladder is the same size as his head, his kidneys are most certainly damaged, and his lungs may not be developing. He says that we could terminate the pregnancy, do nothing and wait for the pregnancy to terminate itself, or we could try a procedure he has done on a few other patients with measured success. I begin to awaken from the daze the anvil has caused as he says procedure. My child is in danger and there's something I can do about it.

It's serious. This won't fix everything. Some damage has already been done. I want you to go home and think about it. If you decide to do the amnio-infusion, come back this afternoon and we will give it a try. Dr. Al-Masry is serious but compassionate. I can tell he doesn't want to give us the impression that everything is going to be ok, but he also wants to help us if we want the kind of help he can offer.

\section{Adam's:}

Lindy did most of the talking. In this moment, as best I could tell, we were in complete agreement: do what can be done to save our child. When Dr. AlMasry laid out our options, I remember very well Lindy's confident question to his assertion that we get a second opinion: Is any other doctor in this town going to tell us to do anything other than terminate? His answer, almost in resignation, was No. In his assessment, his pathway to treatment and potentially saving the life of our child was the exception and not the rule. That was good enough for us. There was a plain resolve in his response, and for that I am grateful. Never again, not once, did I get a hint that he was not fully with us and for us. Over the coming weeks, he worked intently, to the point that his hands cramped from the long, slow process of exerting pressure on a giant syringe attached to the smallest possible needle. What we endured, he endured.

Dr. Al-Masry confirmed his intention to proceed as soon as possible. We were to head home and return for a procedure later in the afternoon. I don't remember leaving the room with the round table, much less the office, or the ride down the elevator. Outside, it was one of those beautiful early spring Florida days, sunny, a bit windy and bright. The car was warm. I remember nothing of the ride home.

We go home and sit on the couch, listening to the clock tick away the seconds... minutes... hours. We try to pray, but words are difficult to form. Our hearts are broken, so the praying is raw, spiritual groaning (Romans 8:26). With my knees pulled to my chest, I call my friend Karen who saw Dr. Al-Masry for her pregnancy a few weeks ago. Although we have seen the same specialist for high risk pregnancies, we determine that we sit at opposite ends of the risk spectrum. I wish I could join her at her end. 


\begin{abstract}
Adam's:
When we got home, we called family and friends. I had developed into a young man who did his best not to cry. I did not care for this feature of my character; I admired expressiveness in men, but I had yet to learn to live in the tension of sometimes letting my emotions reign. I cannot remember whether I had shed many tears during the appointment, but when I called my father, my emotions let loose. I was barely able to articulate what we had learned and what we were facing. I have several vivid memories of my father in tears. His emotional moments sometimes give me permission to draw back the defenses around my heart and to let the tears fall. This time, when the pain of my present experience met the security of my father's voice, I cried and cried.
\end{abstract}

With tear-stained faces, we return to the downtown area, this time to the hospital. No one knows what to do with us at the hospital. On the fourth floor, they do the same thing every day. Women come in, they go to triage, they have babies, and they go home. I don't fit the script, so there is much confusion on the face of the woman at the desk. Eventually, someone escorts me to a procedure room where I don a standard issue hospital gown, the first of hundreds I will wear over the course of the next seven months.

Dr. Al-Masry and Valerie come into the room and I sit in a strange reclining chair, the likes of which I have only seen in $\mathrm{OB} / \mathrm{GYN}$. Valerie finds the baby on the sonogram and Dr. Al-Masry inserts a foot-long needle into my stomach and into the baby's bladder to extract the fluid he is retaining. This is a version of an amniocentesis, but normally the needle would simply extract amniotic fluid from around the baby. In my case, that's not possible because there is no amniotic fluid around the baby, it is all inside. After the baby's bladder is decompressed and a sample is obtained, the difficult work begins. Dr. Al-Masry has to find a pocket of fluid around the baby in order to infuse more fluid, but the baby appears to be vacuum-packed. After much searching on the sonogram, Dr. Al-Masry and Valerie find a pocket that is only $5 \mathrm{~mm}$ in size under the baby's bottom. The needle is $3 \mathrm{~mm}$. The amount of room for error is the same as the width of the wedding band I nervously twist around my finger.

I feel discomfort with every movement of the needle, but I quickly learn to hide the pain because Dr. Al-Masry is worried about me. He constantly reminds me he can stop at any time if it is too painful. I don't care about the physical pain. I have already suffered a crushing blow today. That foot-long $3 \mathrm{~mm}$ needle will never compare to what the anvil delivered. After several tries, Dr. Al-Masry gets his needle inside that tiny pocket. He begins to infuse fluid around the baby. As the warm saline rushes over the baby's bottom, he begins to wiggle it back and forth. That's when we get our first clear view. It's a boy. We name him Will.
Adam's:

With the success of the infusion and the little boy kicking on the monitor in his newfound freedom, I found myself floating in new and strangely calmer waters. The day had been a flood of perilous new possibilities for my life. But when Will began to shimmy on that screen he became mine for the first time, and I laughed. A twinge of fatherly pride awakened. I was in no way ready to break out cigars, but I felt far less afraid of what we were facing. Here was my son, lurking dangerously in harm's way. But he was not alone. He had the resolve of his parents and the skill of a well-trained physician and his assistant to help. I had my marching orders. Though I was in desperate need of sleep, I had a clearer vision of my role in the way ahead.

A new story of my life began to take shape as I dressed myself that afternoon. Time to put on your game face, I thought as I pulled the bill of my ball cap down even with my brow. Had I known then what I know now, I wonder if I would have been more confident that my child would survive or more frightened of the days ahead when we would face waves of medical crises and surgeries. But knowing the future is impossible. I knew enough then. I knew that I decided to fight for Will's life. It was an option most women in such a position do not have. The intersection of personal resources, technological advancement, and a physician willing to think outside the box gave me the opportunity to make a choice offered only to the most fortunate in the world. Later I would learn of the opposition, people who told me to consider my baby's potential quality of life. These challenges didn't cause me to regret my decision to act radically in an effort to save my baby, but they tempered my enthusiasm as I realized the crisp family photo I had envisioned was really a gray Polaroid that would take years to develop. No one knows what the future holds, but most people think they have a pretty good idea. I had become one of the few who realize how uncertain the future can be. One day, my greatest concern for my baby was the quality of the crib. Then next day I was concerned about the quality of his life. This unpredictable and shocking turn of events led me to understand that none of us knows where we are going.

Not only was my Polaroid developing to reveal a family I hadn't expected to see, but this image was also helping to frame my experience in new ways. When I encounter parents of newly diagnosed ill children, sometimes it's like watching a replay of my life. After a diagnosis, parents can't see things the same way anymore. Various frames are tried: hope? despair? anger? selfblame? Each shifting frame is a new look at past, present and future in an effort to explain, What is it that's going on here? (8). ${ }^{9}$ Everything looks different. The taken-forgranted joys of the past may never be reclaimed. The taken-for-granted unlimited potential for the future has been brought to the sobering reality of a ticking clock and 
limits on everything. Parenthood nightmares have become rational projections of the future. The hopes and dreams are what now seem irrational. Parents do not know how to proceed.

In the midst of grappling with the past and the future, there is the present reality, a daily walk down an unlit path with no map and no guide. This territory is new for us. The neat, sterile maps provided by the institutions of healthcare do not fit our experiences. ${ }^{10}$ Frank explains, we find our way through illness by telling our stories. ${ }^{2}$ As Adam and I share our story, we are co-mapping our journey. In order to find our way through illness, it is something we must do.

That day in the waiting room, I resisted the survival stories in the binder. I believed a good life would be lost if I became a survival story. Within the hour, though, I found myself in a small conference room searching for a way to the restitution narrative Frank describes as a kind of illness story. ${ }^{2}$ I wanted to go back to an illness-free life. Now, I do not see our story as one of survival or restitution. We have not merely escaped death, nor have we recovered the past. We have something new, perhaps in line with Frank's quest narrative, but simply put, ours is a story of life.

Before Will, I had a strong sense that I was in control. Smart, calculated, and untouched by tragedy, I was ready and confident to take on anyone or anything. After all, I was most likely to succeed. I studied theology for three years in seminary and believed God is omnipotent. But somewhere between my head and my heart, the information became confused, and I lived my life as though the power was mine to wield. Blind to my own powerlessness, I skimmed the surface of life.

With the news of my baby in peril, for the first time in my life, I had to walk by faith in the midst of grave uncertainty. I began to grope for practical applications for the theological ideas in my head. The God I had attempted to understand through knowledge became my only hope in the midst of a million questions I knew I could never answer. It was like learning to walk again. I had to go slowly, one step at a time, without getting too distracted by what was behind me or the obstacles ahead.

Fourteen years and two more sons later, I continue to move slowly. It is difficult and beneficial to my life. In order to take Will anywhere, we must be prepared with a load of supplies. We carry medications, special food, a feeding pump, and a bottle of water and syringe for giving him fluid through his feeding tube. For a typical outing, Will needs at least two backpacks plus a wheelchair. If we plan to be gone for more than a few hours, we have to make sure we have the means and a place to catheterize him. When traveling with a group, we simply cannot keep up.

Coming in last place grants me the opportunity to see things I used to miss along the way. Mostly, I see people I never noticed before. I see the man who bags my gro- ceries, gives me a hug and says, We're friends, aren't we? We're friends!

I see the neighbor who mumbles a response to my greeting as he shuffles to the convenience store every morning.

I see Will's classmates as they greet him with enthusiasm when we pull up to school.

I also see other families in the hospital; I see where they struggle. I see where maybe I can help.

Before I had Will, I saw none of these people.

Due to our slow pace, I am not always quick to agree to family adventures, but recently, we decided to take all of our kids to LegoLand. Having experienced other theme parks, I was concerned about taking Will here. I worried because there is not a lot for him to do in a theme park. For the first several hours of the day, Will showed little interest in the few rides we felt would accommodate him. He spent most of the time waiting on his younger brothers. After Will and I emerged from a half-hour bathroom session in which I had catheterized him while at least a dozen people knocked on the family restroom door, my husband suggested we put Will on something called The Bouncing Beetle. The Bouncing Beetle has a seat that goes up and down unpredictably. The other boys had enjoyed it while Will and I were monopolizing the family restroom, and they agreed with daddy that Will might really like it. Might.

As Will, my youngest son and I strapped ourselves in, Adam took our middle son to ride a roller coaster. I was outnumbered: two kids to one mom. I did not have an exit strategy, in case things went awry. While pointing to Will, I told the attendant, He's either going to love this or hate it. I have no idea which. So just be prepared for screaming. She looked at me nervously. When we were ready, she pushed the button.

It started with a little yell. Then there was a giggle. The giggle turned into a full-blown belly laugh. It was the kind so deep it's contagious. And I caught it. Everyone began laughing with Will as we went up and down and down and up. In spite of the line of people waiting, the attendant told us to stay put and we bounced up and down on the ride three or four more times. Will laughed hysterically each time. His laughing was only matched by my own delight that he was enjoying the ride. When Adam and my other son came back from the roller coaster, we were still on The Bouncing Beetle. Adam pulled out his phone and took a video of us bouncing and laughing. This was a moment worth capturing. Even the attendant, who must have watched hundreds of other people bounce and squeal that day, was laughing with Will.

\section{Adam's:}

We love our life today. It is far from the promise of doom and gloom that seemed so inevitable on that painful Tuesday. Our son and his care are complicated and at times extremely challenging. Occasionally, someone invites me to wonder at what Will would 
have been like had he not been born early and with compromised kidneys. I find that exercise foreign and disconcerting. The child that I can imagine is nothing more than that: a vague thought in my obviously cloudy brain. I find no joy in that imagined person. I have no mysterious and absolute obligation to love, protect, train and provide for him. The son I have is the son that first appeared on that ultrasound monitor, shaped a little like Barney, the goofy purple dinosaur. The son I have is the one with my hair and skin tone. The son I have is the son I love. That other child is not and could never be Will, and to wish for Will to be someone or something other than what he is would mean to not delight in the one who sits smiling wryly in front of me. I have yet to meet the person who knows Will and does not agree with me.

It was naïve to believe that the life I thought I wanted was better than the life I had been given. But how in the world was I to know that then? As I write these words a few days before Easter Sunday, I think about my job as the worship director in a church. I am responsible for planning and preparing our services from the first welcome to the final benediction. Resurrection Sunday proclaims a profound mystery, lost to most of us who are so ingrained in only what we can touch and taste and smell. I am right there in the middle of the masses who would rather not think about death, let alone face the impending death of my child. I get paid to offer the story that claims victory over the tragedy of death.

But really, my experience also teaches me that resurrection is very real. Even the seed must die so that the tree can grow (John 12:24). The message of my faith is what I want not just in my soul and spirit but also in my fingertips and toes, permeating my every thought and reaction to every unexpected tragedy and delight. I have lost count of the number of times I've prayed that Will would learn to walk. Somewhere in the middle of those prayers, I realized that I, like Will, need to learn to stand, bear the weight of my body and take a step. I do not want to float above my circumstances, unscathed and not acknowledging the real hurt and confusion. The Resurrection implies that death is real. I hope to be more fully committed to a life of love, joy and hope, even in the face of death and pain, for myself and for those who walk with me in the shadow of big trees, in the cool of the evening as the sun sets and the sky grows dark.

A few days after we met Dr. Al-Masry, we stopped at a park to eat lunch in the warm Florida spring air. Dr. AlMasry was keeping a close eye on me, with frequent procedures that would eventually become a seven-week hospitalization. The hazy future of our lives and the life of our child hung like a filter between us and the beautifully clear day. We sat at a picnic table in the park to eat our lunch and attempt a moment of levity. Ironically it was the nearby playground, a place designed for carefree fun that pulled me deeper into the haze of uncertainty. Adam and I exchanged hesitant words about the future of our child, wondering if he would ever play on a playground. We shared an unspoken understanding that if the image of healthy children at play was startling and unsettling, we might never see the world the same way again. We were correct, but what we didn't know was that the new eyes with which we would see the world would not only cause us to grieve more deeply, but also allow us to laugh more heartily, take time to appreciate small successes, and experience the world in a completely new way. Our family photo would not be a still shot of posed and practiced smiles facing the camera, but rather an action shot of a family of five, mouths agape in laughter, looking at one another.

In our experience of crisis, Adam and I chose to grieve together, pray together, work together and trust one another. This helped to build our relationship into something more resilient than it had previously been. This co-constructed project has also strengthened our relationship, reminding us of our perseverance during the darkest days of our lives. Additionally, the project helps us to continue to discover new depths and insights into one another. Since Will came into our lives, we've never regained a clear vision of the future. Our youngest son recently asked me, Do you think Will will ever get married? As our other boys become aware of the difference between Will's life and theirs, we work through the questions together. Each question follows another. They string together into the unknown future awaiting us. How will we live? What will we be? I don't know, precisely. But the lessons of the past fourteen years teach me that the best way to face that future is slowly, one step at a time and together.

Patients and families facing medical crises often ask for predictions of the future, and medical practitioners offer percentages of survival rates and success rates in an effort to address these questions. The concept of evidencebased medicine rests upon the knowledge of what treatments have worked in the past and are predicted to work in the future. However, when there is no evidence and no one can predict what will happen, it is easy to panic, avoid the situation or despair. Adam and I share this story to encourage patients, families and practitioners alike. There is life in the not-knowing. We have never based our decisions for Will solely on medical evidence, and often there has been little medical evidence to guide us. Our own understandings, faith, and the guidance of patient and wise medical practitioners help us walk this mysterious journey that is much more than a medical drama; it is our life.

\section{References}

1. Ellis C, Bochner A. Telling and performing personal stories: the constraints of choice in abortion. In: Ellis C, Flaherty MG, eds. Investigating subjectivity: research on lived experience. Newbury Park, CA: Sage Publications; 1992. pp 79-101. 
2. Frank A. The wounded storyteller: body, illness and ethics. University of Chicago Press; 2013.

3. Ellis C, Adams TE, Bochner AP. Autoethnography: an overview. Historical Social Research/Historische Sozialforschung 2011;36:273-90.

4. Chang H, Ngunjiri F, Hernandez KAC. Collaborative autoethnography. Berkeley CA: Left Coast Press; 2012.

5. Rennels TR, Paxton BA. Sudden death, sudden friend: exploring the role of friendship in continuing bonds with the deceased. Depart Crit Qual Res 2013;2:182-212.
6. Ellis C. The ethnographic I: a methodological novel about autoethnography. Walnut Creek, CA: AltaMira Press; 2004.

7. Coles R. The call of stories: teaching and the moral imagination. Boston: Houghton Mifflin Harcourt; 1989.

8. Parry A. A universe of stories. Family Process 1991;30:37-54.

9. Goffman E. Frame analysis: an essay on the organization of experience. Boston: Northeastern University Press; 1974.

10. Davidson LG. Would you like a map? Explorations in hospital cartography. Depart Crit Qual Res 2016;5:23-36. 